\title{
Applying Total Productive Maintenance in Aluminium Conductor Stranding Process
}

\author{
O. Joochim ${ }^{1}$ and J. Meekaew ${ }^{2}$ \\ ${ }^{1}$ Institute of Field Robotics, King Mongkut's University of Technology Thonburi, \\ Bangkok, Thailand \\ ${ }^{2}$ Aluminium Conductor Department, Bangkok Cable Co., Ltd. (Chachoengsao \\ Factory), Chachoengsao, Thailand \\ E-mail:orapadee.joo@kmutt.ac.th; jumnong.m@bangkokcable.com
}

Received 20 July 2016; Accepted 10 September 2016

Publication 30 September 2016

\begin{abstract}
The purpose of this paper is to apply a total productive maintenance (TPM) technique for increasing the effectiveness in producing aluminium stranded conductors in order to reduce waste problems of the machine and improve the quality of the production. Two pillars of TPM activities for autonomous maintenance and focused improvement are established. Machines that have low overall equipment efficiency (OEE) are chosen as prototype machines. Training program for employees about the production work, cleaning activities to discover abnormal conditions, corrective actions during abnormal operations and a one point lesson (OPL) to educate operators for the production process are implemented. Autonomous maintenance standards are also created. Pareto analysis is used to quickly determine the critical equipment in the factory. A corrective action team is selected for improving the operation of the process. The research is evaluated by comparing the OEE of prototype machines based on production problems occurred before and after the improvement. The results show that the TPM implementation reduces the downtime from $7,730.80$ minutes per month to 4,942.20 minutes per month, the loss of the scrap from 4,570.00 kilograms per month to 2,236.67 kilograms per month. The OEE is increased from 67.21 percent to 72.14 percent.
\end{abstract}

Journal of Industrial Engineering and Management Science, Vol. 1, 19-42.

doi: 10.13052/jiems2446-1822.2016.002

(C) 2016 River Publishers. All rights reserved. 
Keywords: Total productive maintenance, overall equipment efficiency, one point lesson.

\section{Introduction}

Thailand's residential electricity consumption continues to grow according to the economic growth of the country. The rapid increase in Thailand's electricity demand requires a substantial amount of electric wires and cables. Bangkok Cable Company Limited is a leader in manufacturing electric wires and cables in Thailand. Bangkok Cable's first factory is located in Samutprakan Province, and its second factory is situated in Chachoengsao Province. The company offers covering all types of bare and insulated conductors.

The electric cable production process is demonstrated in Figure 1. The production process begins with feeding aluminium rods into the melting process to produce aluminium conductors. In the next step, the conductors are extruded. After the extrusion, the conductors are stranded. The conductors are then packaged into the coils and reels. Insulated conductors must be made before packaging, if the conductors are required to be insulated or covered. Three primary types of insulating materials used are polyvinyl chloride (PVC), polyethylene (PE) and cross-linked polyethylene (XLPE). Production quality control is strictly executed on every step of production for the highest quality.

However, it was found from the production data collection of aluminium conductors between July to December 2014 that the overall equipment

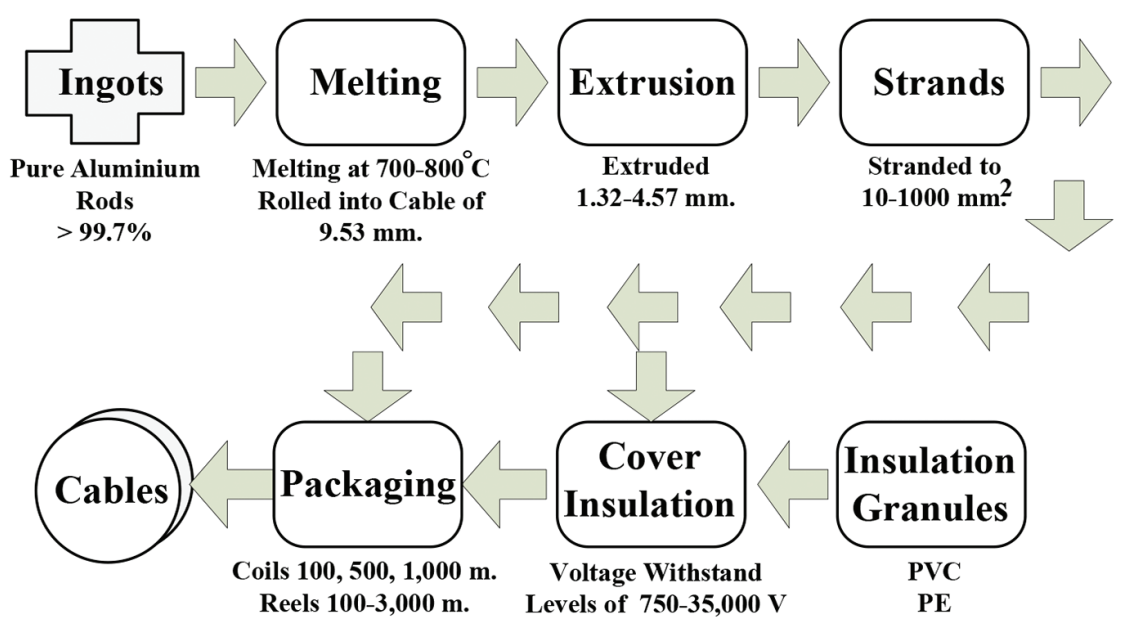

Figure 1 Electric cable production process. 
efficiency (OEE) is equal to 80.96 percent. OEE of the production of aluminium stranded conductors is equal to 70.46 percent which is the lowest comparing with other stages of the production. By increasing OEE, time and waste losses will be decreased. Therefore, it is possible to expand the production in the future. The aim of this paper is to study the effectiveness and implementation of TPM program for the production process of aluminium stranded conductors of an electric wire and cable manufacturer (i.e., Chachoengsao Factory of Bangkok Cable) [1].

\section{Study Methodology}

\subsection{Total Productive Maintenance (TPM)}

TPM has been acknowledged as a manufacturing strategy for helping to increase the productivity and overall equipment effectiveness. The concepts of TPM has been introduced and developed by in M/S Nippon Denso Co., Ltd of Japan in 1971. TPM has been widely implemented, and there are a number of case studies of TPM applications in the literature [2].

The basic practices of TPM are frequently called the pillars or elements of TPM. The core TPM is categorized into eight TPM pillars or activities

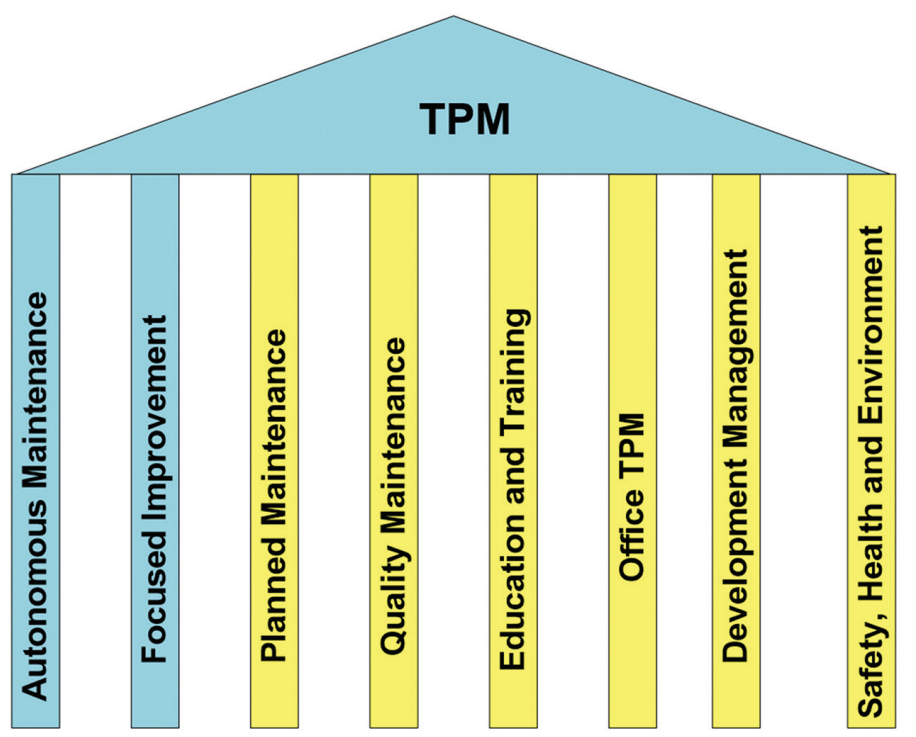

Figure 2 Eight pillars of TPM (from JIPM). 
for accomplishing the manufacturing performance improvements. The eight pillars are autonomous maintenance, focused improvement (Kobetsu Kaizen), planned maintenance, quality maintenance, education and training, office TPM, development management, as well as safety, health and environment [3]. In order to increase the overall effectiveness and reduce times and wastes during the production of aluminium stranded conductors, autonomous maintenance and focused improvement which are the main TPM pillars are used in this paper.

Autonomous maintenance means maintaining one's own equipment in a good condition by one self. The purpose of this pillar is to prepare the operators to be able to take care of small maintenance tasks, hence allowing the skilled maintenance operators for spending time on more value added activity and technical repairs. The operators are therefore responsible for upkeep of their equipment on daily basis to prevent it from deteriorating or break down $[3,4]$. There are 7 steps of autonomous maintenance as illustrated in Table 1.

Focused Improvement concentrates on reducing losses in the work place in order to improve operational efficiency. The targets of the improvement are zero losses (identify and eliminate losses), remove unsafe conditions, improve effectiveness of all equipment and reduce operation and maintenance costs. The principle of this pillar is that "a very large number of small improvement is more effective in an organization than a few improvement of large value" $[4,7]$.

\subsection{Overall Equipment Efficiency (OEE)}

OEE is an essential measure in TPM used as a quantitative metric for measuring the performance of a productive system. OEE is used to measure the success of TPM implementation program. The principle goal of TPM is

Table 1 Seven steps of autonomous maintenance [5, 6]

\begin{tabular}{|c|c|c|}
\hline Change & Step & Objective \\
\hline Machine & Step 1: Inspected Clean up & The ability to find the \\
\hline Change & $\begin{array}{l}\text { Step 2: Eliminating the Difficulties } \\
\text { and Source of Outbreaks } \\
\text { Step 3: Formulating Autonomous } \\
\text { Maintenance Standard }\end{array}$ & $\begin{array}{l}\text { abnormality, and the ability to } \\
\text { inspect the abnormality }\end{array}$ \\
\hline Human Change & $\begin{array}{l}\text { Step 4: Overall Check Up } \\
\text { Step 5: Autonomous Check Up }\end{array}$ & $\begin{array}{l}\text { Improvement of Machine } \\
\text { Deterioration }\end{array}$ \\
\hline $\begin{array}{l}\text { Environmental } \\
\text { Change }\end{array}$ & $\begin{array}{l}\text { Step 6: Standard Preparation } \\
\text { Step 7: Continuous Improvement }\end{array}$ & $\begin{array}{l}\text { Maintenance Management } \\
\text { from Machine Users }\end{array}$ \\
\hline
\end{tabular}


to increase the overall equipment efficiency. The three main components of OEE are equipment availability (A), performance efficiency $(\mathrm{P})$, and quality rate $(\mathrm{Q})$. OEE can be calculated as follows $[8,9]$.

$$
\begin{gathered}
\text { OEE }=A \times P \times Q \\
A=\left[\frac{\text { Loading Time }- \text { Downtime }}{\text { Loading Time }}\right] \times 100 \% \\
P=\left[\frac{\text { Ideal Cycle Time } \times \text { Total Pieces }}{\text { Operating Time }}\right] \times 100 \% \\
Q=\left[\frac{\text { Total Product }- \text { Defects }}{\text { Total Product }}\right]
\end{gathered}
$$

\subsection{One Point Lesson (OPL)}

The OPL form is a learning tool which helps to communicate TPM training concepts to participants and employees. This form is structured for motivating the trainer to establish all substantial activities onto one simple and easy to use [6]. OPL is the lessons learnt by operators after carrying out the autonomous maintenance or focused improvement activities. A small-group-activity leader marks the activities into the OPL report. The enhancing of OPL allows the increase of the improvements done by the operators. Thus, the operators are becoming more skillful [10].

\section{Case Study}

As in Figure 3, The aluminium conductor stranding process starts with passing extruded aluminium conductors into each layer of the stranders. The conductors are stranded according to the standard of the strand length. Each conductor is pulled by using a capstan and the stranders are rotated at the same time so that the conductors are twisted. The aluminium stranded conductors are then sent to be stored.

\subsection{Problem Definition}

Table 2 shows the data of the production plans, good products, wastes, loading time and downtime of the production process for all departments were collected in 6 months (from July to December 2014). From Table 2, the 


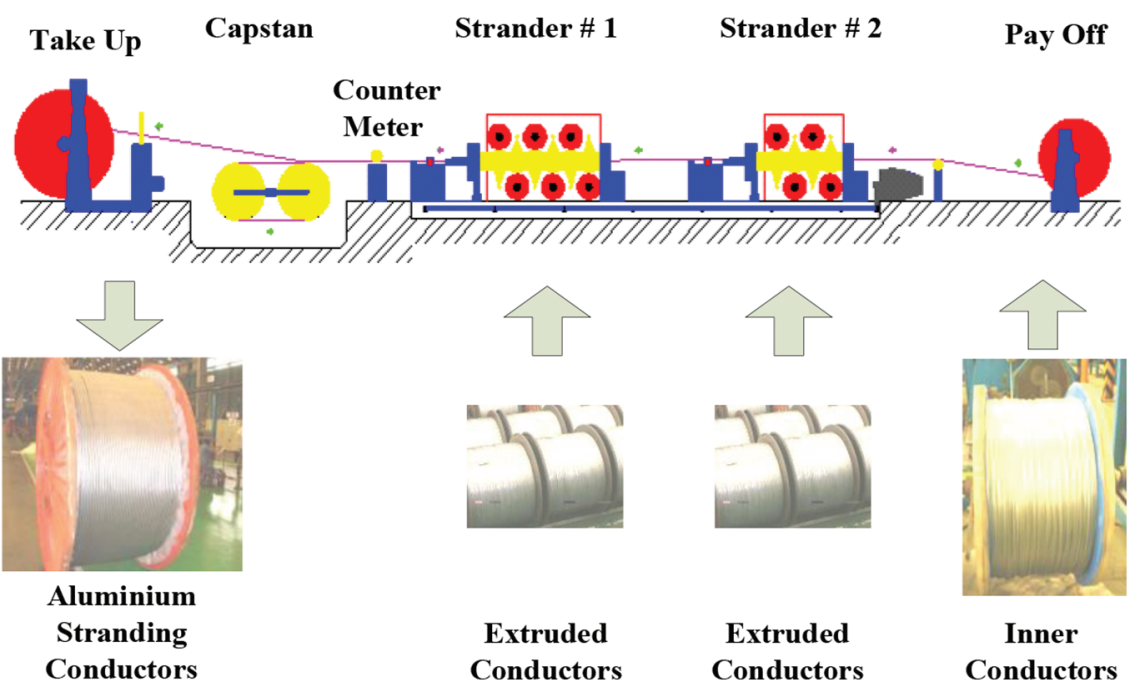

Figure 3 Electric cable production process.

Table 2 The production data of all departments

\begin{tabular}{lccrrr}
\hline & $\begin{array}{c}\text { Production } \\
\text { Plans }\end{array}$ & $\begin{array}{c}\text { Good } \\
\text { Products } \\
\text { (Tons) }\end{array}$ & $\begin{array}{c}\text { Wastes } \\
\text { (Tons) }\end{array}$ & $\begin{array}{c}\text { Loading } \\
\text { Time } \\
\text { (Hours) }\end{array}$ & $\begin{array}{c}\text { Downtime } \\
\text { (Hours) }\end{array}$ \\
\hline Melting & $6,202.08$ & $6,132.77$ & 69.31 & $1,838.84$ & 140.94 \\
Extrusion & $5,533.32$ & $5,530.85$ & 2.47 & $6,178.94$ & $1,014.93$ \\
Stranding & $5,921.89$ & $5,806.89$ & 115.00 & $27,141.63$ & $3,815.38$ \\
Medium Voltage & $3,298.77$ & $3,246.77$ & 52.00 & $6,453.47$ & 447.69 \\
Insulation & & & & & \\
Low Voltage Insulation & $5,206.89$ & $5,169.65$ & 37.24 & $12,672.84$ & $1,175.80$ \\
PE and PVC Grains & $3,794.84$ & $3,793.50$ & 1.34 & $7,559.00$ & 285.00 \\
Total & $29,957.79$ & $29,680.43$ & 277.36 & $61,844.72$ & $6,879.74$ \\
\hline
\end{tabular}

equipment availability (A), performance efficiency (P), quality rate $(\mathrm{Q})$ and overall equipment efficiency (OEE) are calculated as in Table 3 [11].

The OEE of each department from Table 2 is shown in Figure 4. It can be noticed from Table 3 and Figure 4 that the average OEE score is equal to 80.96 percent. The OEE of the production of aluminium stranded conductors is equivalent to 70.46 percent which is the lowest comparing with other stages of the production. Therefore, this paper intends to increase the OEE of the stranding process. Table 4 demonstrates the production data of the aluminium conductor stranding process. 
Table 3 Overall equipment efficiency of the production

\begin{tabular}{lcccc}
\hline Department & $\mathrm{A}(\%)$ & $\mathrm{P}(\%)$ & $\mathrm{Q}(\%)$ & $\mathrm{OEE}(\%)$ \\
\hline Melting & 92.34 & 95.90 & 98.88 & 87.56 \\
Extrusion & 83.57 & 93.63 & 99.96 & 78.22 \\
Stranding & 85.94 & 83.61 & 98.06 & 70.46 \\
Medium Voltage Insulation & 93.06 & 94.00 & 98.42 & 86.10 \\
Low Voltage Insulation & 90.72 & 93.00 & 99.28 & 83.77 \\
PE and PVC Grains & 96.23 & 96.50 & 99.96 & 92.83 \\
Average & 88.88 & 92.23 & 98.77 & 80.96 \\
\hline
\end{tabular}

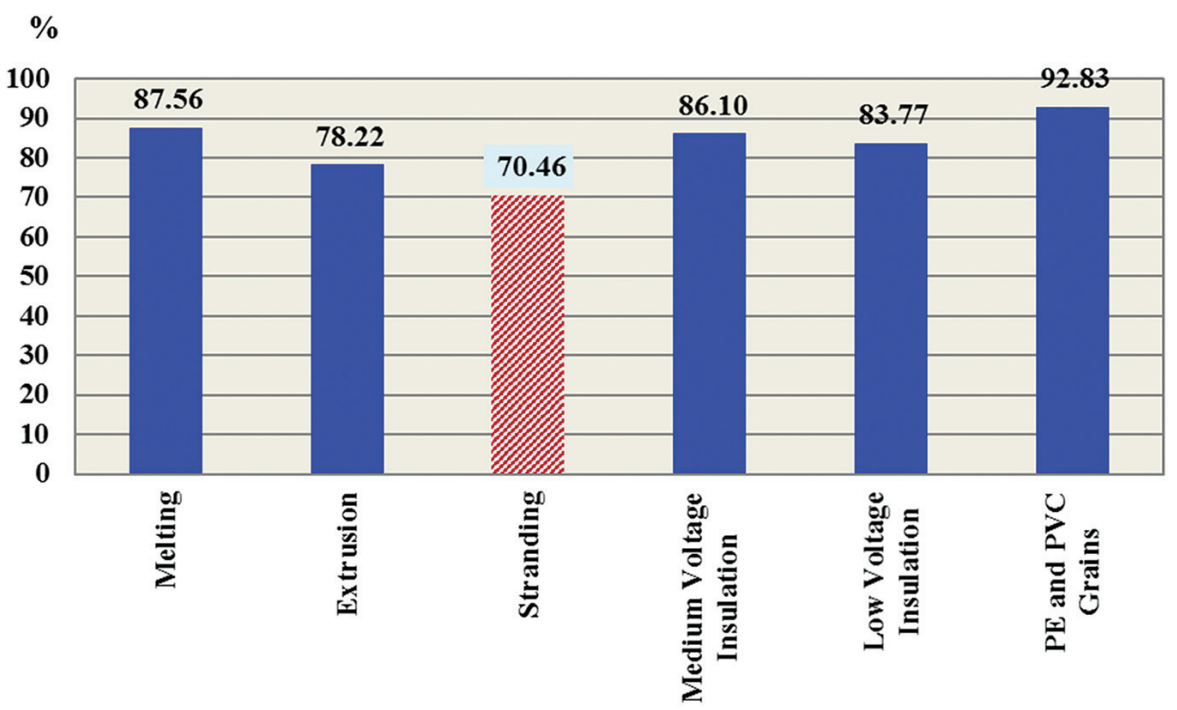

Figure 4 OEE of the production.

By using the data of Table 4, the sample of the OEE calculation for the ST09 strander machine is as follows.

$$
\begin{gathered}
A=\left[\frac{2,597.45 \text { hrs }-430.77 \text { hrs }}{2597.45 \text { hrs }}\right] \times 100 \%=83.42 \% \\
P=\left[\frac{0.0011 \text { (hrs per } \mathrm{m} .) \times 2,400 \mathrm{~m} .}{3.17 \text { hrs }}\right] \times 100 \%
\end{gathered}
$$

$\mathrm{P}$ is calculated from each type of conductors before calculating for the average of the machine. For instance, the idle cycle time is equal to 0.001 hours per meter, the length of produced conductors is equivalent to 2,400 meters, 
Table 4 Overall equipment efficiency of the production

\begin{tabular}{lccccc}
\hline & $\begin{array}{c}\text { Production } \\
\text { Plans } \\
\text { Machine }\end{array}$ & $\begin{array}{c}\text { Good } \\
\text { Products } \\
\text { (Tons) }\end{array}$ & $\begin{array}{c}\text { Wastes } \\
\text { (Tons) }\end{array}$ & $\begin{array}{c}\text { Loading } \\
\text { Time } \\
\text { (Hours) }\end{array}$ & $\begin{array}{c}\text { Downtime } \\
\text { (Hours) }\end{array}$ \\
\hline ST01 & 288.62 & 276.12 & 12.50 & $2,879.46$ & 353.76 \\
ST04 & 635.27 & 617.87 & 17.40 & $2,808.54$ & 462.38 \\
ST06 & 558.47 & 533.72 & 24.75 & $3,097.18$ & 646.67 \\
ST08 & 196.22 & 192.09 & 4.13 & $2,327.04$ & 366.65 \\
ST09 & 561.07 & 535.75 & 25.32 & $2,597.45$ & 430.77 \\
ST11 & 273.04 & 254.54 & 18.50 & $2,690.00$ & 440.75 \\
ST02 & 205.20 & 204.80 & 0.40 & $2,298.25$ & 155.62 \\
ST03 & $1,392.00$ & $1,388.60$ & 3.40 & $2,976.81$ & 306.27 \\
ST05 & $1,560.55$ & $1,553.35$ & 7.20 & $3,188.47$ & 521.00 \\
ST13 & 251.45 & 250.05 & 1.40 & $2,278.43$ & 131.50 \\
Total & $5,921.89$ & $5,806.89$ & 115.00 & $27,141.63$ & $3,815.37$ \\
\hline
\end{tabular}

and the operating time is equal to 3.17 hours. The following is the calculation of $\mathrm{P}$.

After the average of all conductor types is calculated, $\mathrm{P}$ is then equal to $76.83 \%$.

$$
\begin{aligned}
Q & =\left[\frac{561.07 \text { tons } \times 25.32 \text { tons }}{561.07 \text { tons }}\right] \times 100 \%=95.49 \% \\
O E E & =0.832 \times 0.763 \times 0.9549 \times 100 \%=61.20 \% \\
& =84.12 \%
\end{aligned}
$$

The OEE of strander machines are illustrated in Figure 5. The strander machines can be divided into two groups; (1) machines that loading the extruded conductors into steel wheels (i.e., ST01, ST04, ST06, ST08, ST09 and ST11), and (2) machines that loading the extruded conductors into baskets (ST02, ST03, ST05 and ST13). The ST03 and ST09 machines which have the lowest OEE compared with other machines of their group are selected as the prototype machines. The data of the problems of the downtime that do not include the preparation time of ST03 are collected.

The problems are arranged as demonstrated in Figures 6 and 8 depending on the priority of the downtimes and represented by the pareto graph for the data analysis. The collection of the data of quality loss problems is implemented. The arrangement of the problems is done according to the priority of the wastes. The data are illustrated as the pareto graph in Figures 7 and 9. 


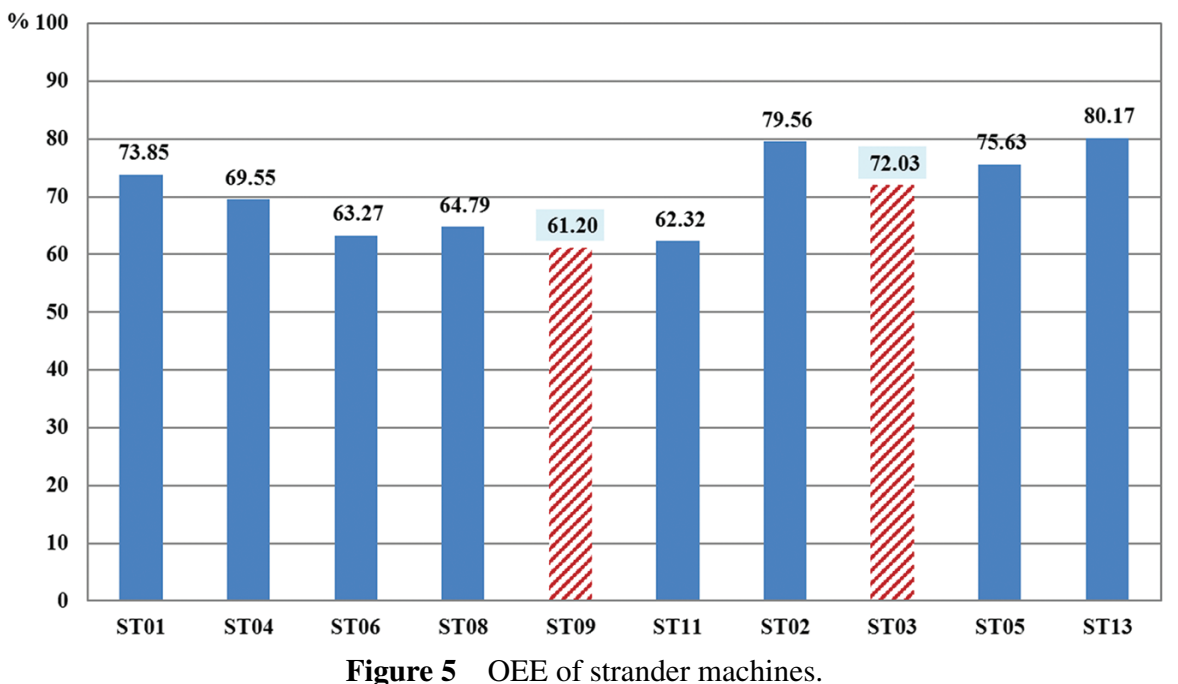

Figure 5 OEE of strander machines.

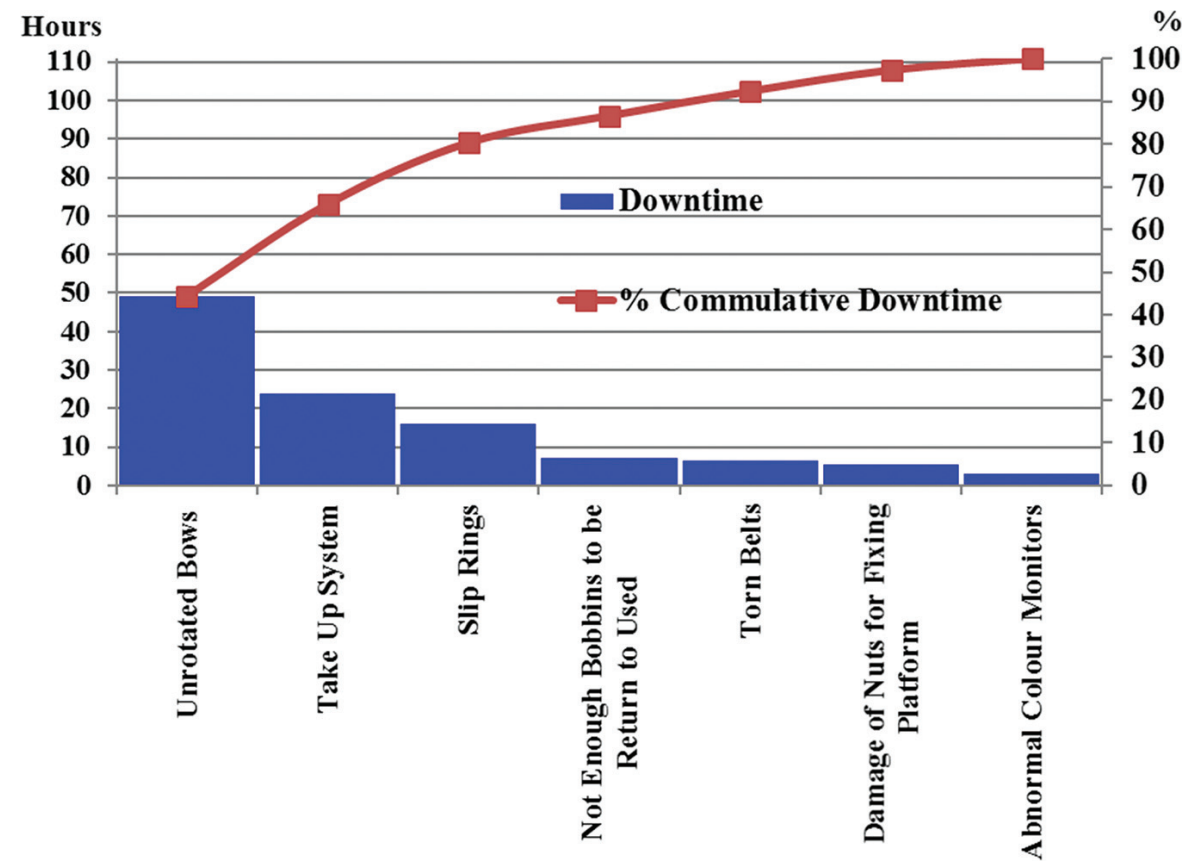

Figure 6 Pareto of the downtime problems of ST03 before the improvement. 


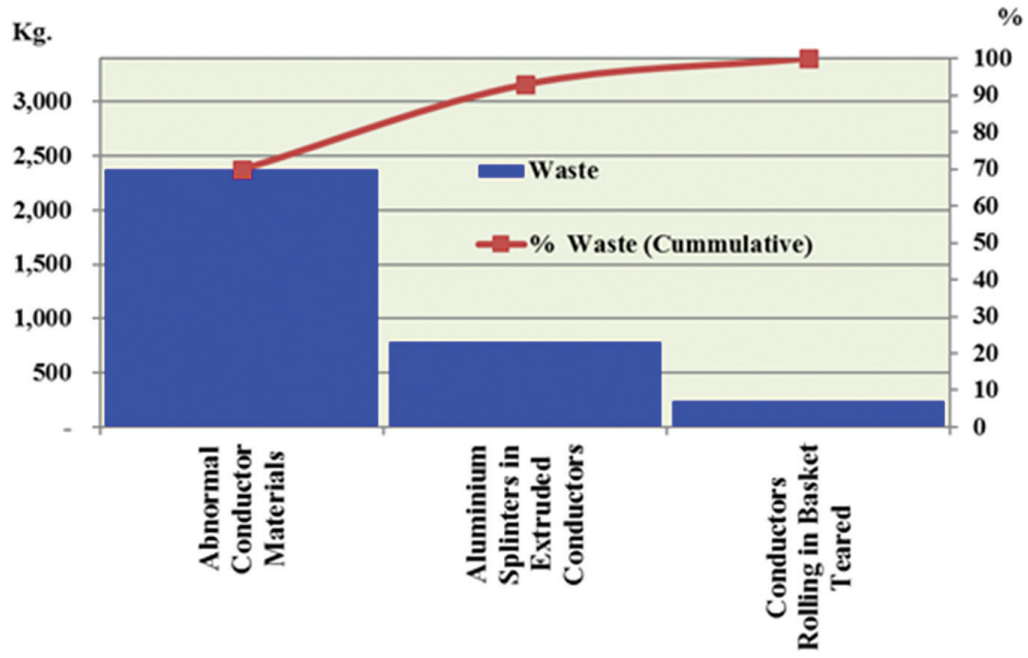

Figure 7 Pareto of the quality problems of ST03 before the improvement.

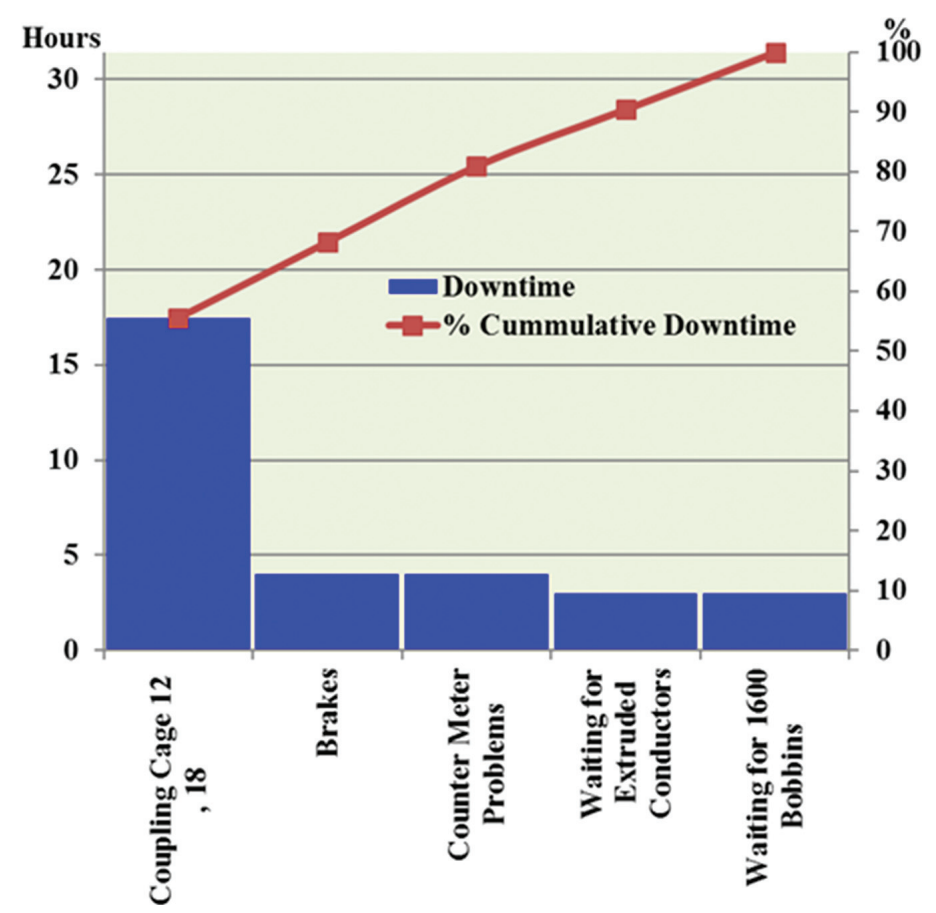

Figure 8 Pareto of the downtime problems of ST09 before the improvement. 


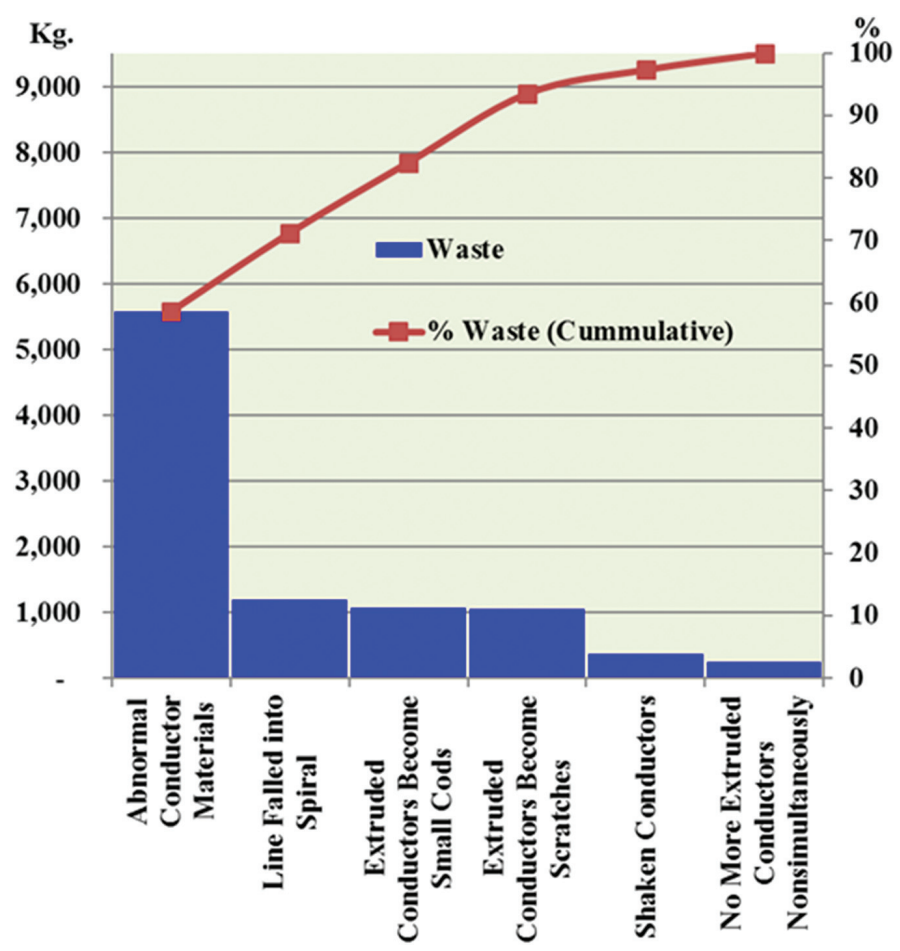

Figure 9 Pareto of the quality problems of ST09 before the improvement.

\subsection{Implementation of Autonomous Maintenance}

Autonomous maintenance is implemented by training the operators of the strander departments 1 and 2 about how to maintain the strander machines (self-maintenance). The operators are divided into two teams for the selfmaintenance works for the ST03 and ST09 machines. The procedure begins by cleaning the machines, finding the abnormality and labeling to demonstrate the abnormality. The equipment used for the primary cleaning, protection and others is prepared. The maintenance is defined to do together every Wednesday.

The cleaning and finding of the abnormality are performed at the same time. The labels are attached at the abnormal parts (see Figure 10). The discovery dates and priorities are specified. The abnormality and correctional solution are defined. The list of the abnormality is made and recorded. The abnormality is corrected. The before and after maintenance data about the problems, solutions and benefits of the maintenance are list. The learning about the finding of the problems and solutions are shared to the related operators by 

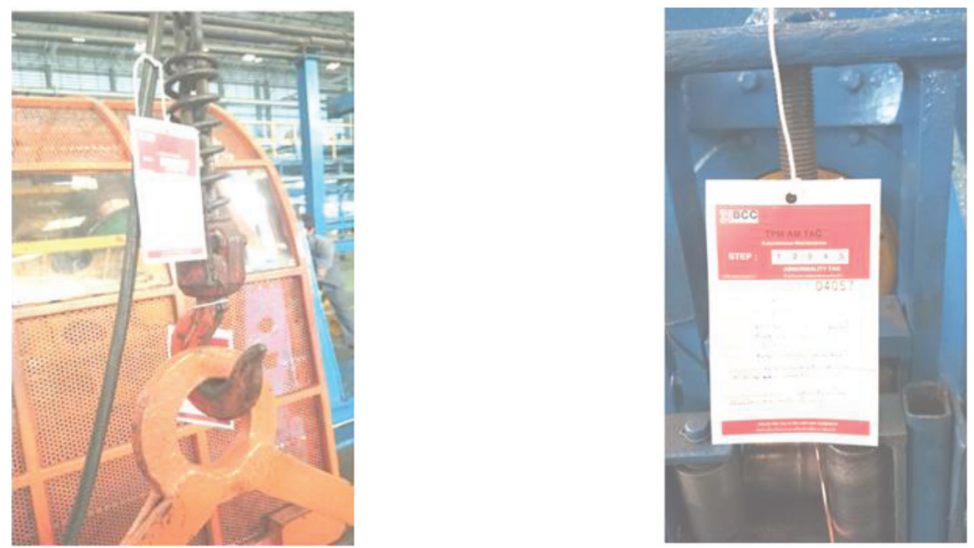

Figure 10 Samples of attached labels at the abnormal parts.

Table 5 Autonomous maintenance works

\begin{tabular}{llccc}
\hline & & & Finished & Operations \\
\cline { 3 - 4 } Procedures & Topics & Amount & Solved & $(\%)$ \\
\hline 1 & Correction of Abnormality & 60 & 53 & 88.33 \\
2 & Training Using OPL & 25 & 20 & 80.00 \\
3 & Lubrication Standard & 8 & 8 & 100.00 \\
4 & Self-Inspection Standard & 4 & 3 & 75.00 \\
& Total & 97 & 84 & 86.60 \\
\hline
\end{tabular}

using OPL. The training using OPL is classified according to the topic, basic knowledge, improvement work or problem. The area for the lubrication is defined. The standard of the lubrication is implemented. The self-inspection of the machines is performed. The self-inspection standard is created. The information about the machine components, lubrication standard, inspection of the operations of the equipment and observation method is used to create the inspection sheet for daily maintenance. Table 5 illustrates the amount of maintenance works. The improvements in abnormalities are listed. The photos of abnormalities before and after the improvement are compared as in Table 6.

\subsection{Implementation of Focused Improvement}

It can be seen from Figures 6 to 9 that a large majority of the problems ( 80 percent) are selected for the improvement according to the pareto analysis. The related workers are defined for the problems consisted of representatives 
Table 6 Samples of abnormality before and after the improvement

No.

from engineering, quality assurance and planning departments. The meeting is set for the related workers in order to solve the problems using the $5 \mathrm{~W} 1 \mathrm{H}$ principle for inspecting the data of the problem characteristics.

The improvement is done corresponding to the defined plan. Subsequently, the downtimes and wastes are reduced. Focused Improvement starts with solving the problem of bows that cannot be rotated. The take up system 
doesn't work. The slip rings are electrocuted. The machines are shut down for fixing. The bows and slip rings are changed. The downtime problem is solved. During the stranding process, the conductors are teared. The cause of tearing is investigated, and the factors of tearing and standard of the inspection are defined. The frequency of inspection and responsible persons are specified. As a result, the losses are decreased. The problems of Coupling Cage 12 and 18 are occurred according to eroding of shafts. The shafts and couplings are changed. The data of the problems after the improvement are collected between January to March 2015, see Figures 11 to 14.

\subsection{Production Data Before and After the Improvement}

After the implementation of TPM for autonomous maintenance and focused improvement, the comparison between before the improvement (from October to December 2014) and after the improvement (from January to March 2015) are investigated. The selected prototype machines are ST03 and ST09 machines. The production data before and after the improvement of the ST03 machine are shown in Tables 7 and 8 respectively. According to Tables 7 and 8 ,

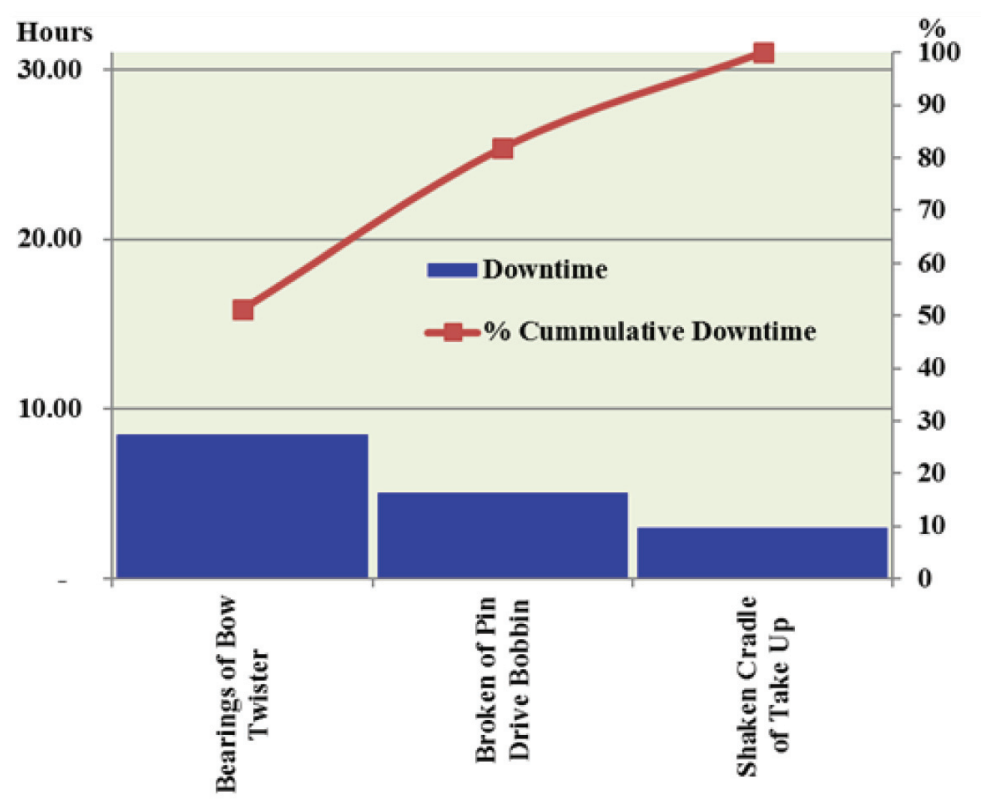

Figure 11 Pareto of the downtime problems of ST03 after the improvement. 


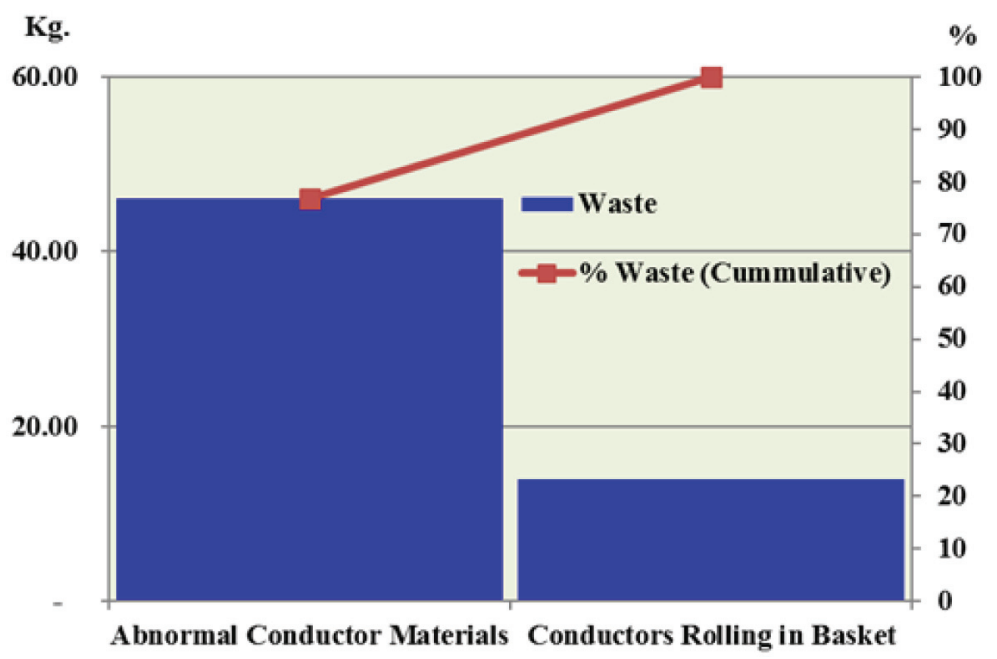

Figure 12 Pareto of the quality problems of ST03 after the improvement.

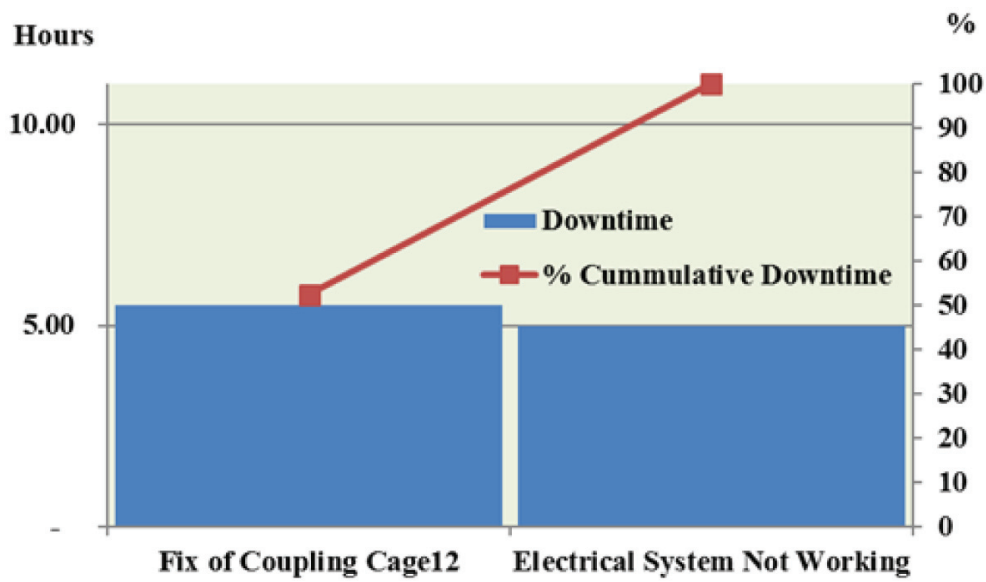

Figure 13 Pareto of the downtime problems of ST09 after the improvement.

the OEE before and after the improvement of ST03 are correspondingly calculated as shown in Tables 9 and 10.

It can be found from Tables 9 and 10 that the average per month of the equipment availability (A) is increased from 88.50 percent to 92.75 percent. The average per month of the performance efficiency is increased from 80.59 percent to 82.93 percent. The average per month of the quality rate is increased 


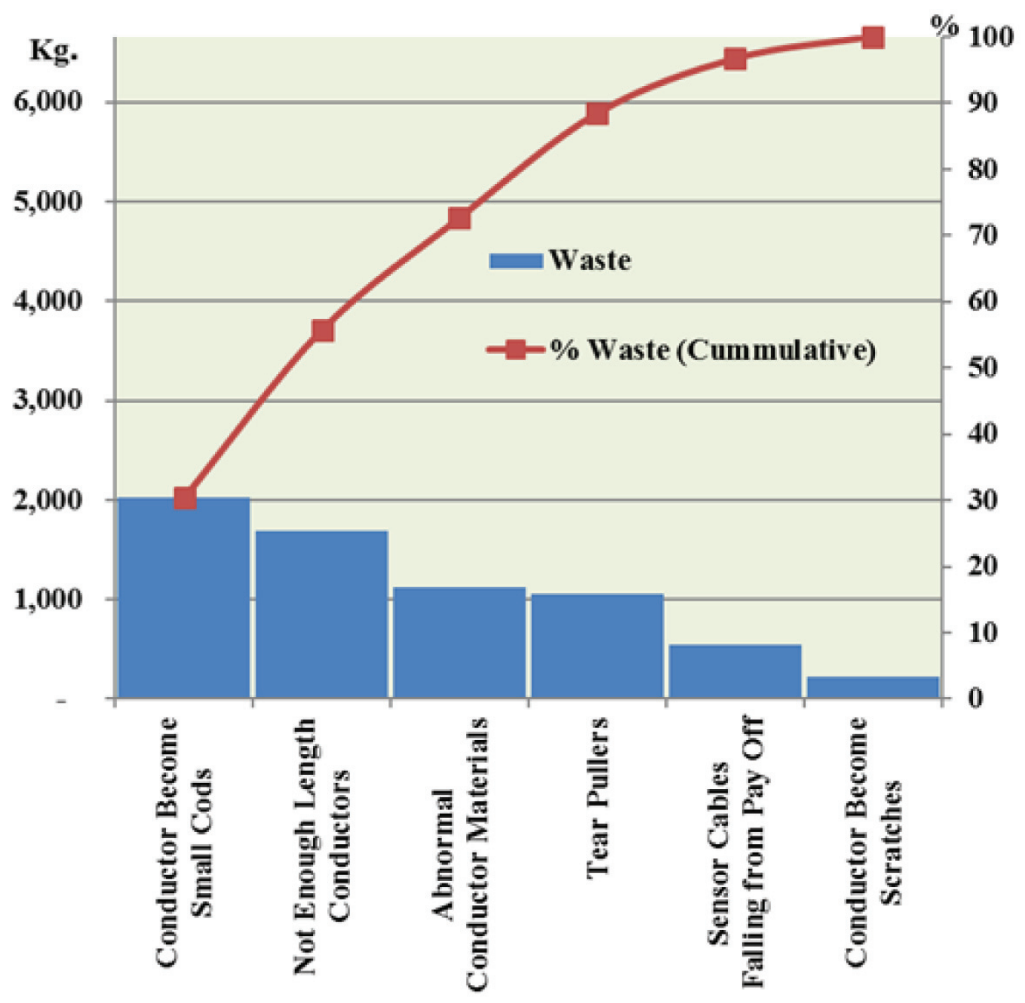

Figure 14 Pareto of the quality problems of ST09 after the improvement.

Table 7 Production data of ST03 before the improvement

\begin{tabular}{lccccc}
\hline & $\begin{array}{c}\text { Production } \\
\text { Plans }\end{array}$ & $\begin{array}{c}\text { Good } \\
\text { Products }\end{array}$ & $\begin{array}{c}\text { Wastes } \\
\text { (Tons) }\end{array}$ & $\begin{array}{c}\text { Loading } \\
\text { Time } \\
\text { (Hours) }\end{array}$ & $\begin{array}{c}\text { Downtime } \\
\text { (Hours) }\end{array}$ \\
\hline October & 226.89 & 226.35 & 0.54 & 499.75 & 58.32 \\
November & 219.26 & 218.86 & 0.40 & 477.75 & 69.71 \\
December & 224.67 & 224.37 & 0.29 & 505.75 & 46.75 \\
Total & 670.81 & 669.58 & 1.24 & $1,483.25$ & 174.78 \\
Average/Month & 223.60 & 223.19 & 0.41 & 494.42 & 58.26 \\
\hline
\end{tabular}

from 99.82 percent to 99.99 percent. As a result, the average per month of OEE is absolutely increased from 70.97 percent to 76.89 percent.

The production data before and after the improvement of the ST09 machine are demonstrated in Tables 11 and 12 respectively. From Tables 11 and 12, the 
Table 8 Production data of ST03 after the improvement

\begin{tabular}{lccccc}
\hline & $\begin{array}{c}\text { Production } \\
\text { Plans } \\
\text { Month (2015) }\end{array}$ & $\begin{array}{c}\text { Good } \\
\text { Products } \\
\text { (Tons) }\end{array}$ & $\begin{array}{c}\text { Wastes } \\
\text { (Tons) }\end{array}$ & $\begin{array}{c}\text { Loading } \\
\text { Time } \\
\text { (Tons) }\end{array}$ & $\begin{array}{c}\text { (Hours) } \\
\text { Downtime } \\
\text { (Hours) }\end{array}$ \\
\hline January & 249.59 & 249.57 & 0.02 & 567.00 & 40.20 \\
February & 79.44 & 79.42 & 0.018 & 225.75 & 16.16 \\
March & 149.77 & 149.75 & 0.02 & 356.75 & 27.00 \\
Total & 478.80 & 478.75 & 0.06 & $1,149.50$ & 83.36 \\
Average/Month & 159.60 & 159.58 & 0.02 & 383.17 & 27.79 \\
\hline
\end{tabular}

Table 9 OEE of ST03 before the improvement

\begin{tabular}{lcccc}
\hline Month (2014) & $\mathrm{A}(\%)$ & $\mathrm{P}(\%)$ & $\mathrm{Q}(\%)$ & $\mathrm{OEE}(\%)$ \\
\hline October & 88.33 & 82.78 & 99.76 & 72.95 \\
November & 85.41 & 76.98 & 99.82 & 65.63 \\
December & 90.76 & 82.00 & 99.87 & 74.32 \\
Average/Month & 88.22 & 80.59 & 99.82 & 70.97 \\
\hline
\end{tabular}

Table 10 OEE of ST03 after the improvement

\begin{tabular}{lcccc}
\hline Month (2015) & $\mathrm{A}(\%)$ & $\mathrm{P}(\%)$ & $\mathrm{Q}(\%)$ & OEE (\%) \\
\hline January & 92.91 & 82.79 & 99.99 & 76.91 \\
February & 92.84 & 82.44 & 99.98 & 76.52 \\
March & 92.43 & 83.57 & 99.99 & 77.23 \\
Average/Month & 92.75 & 82.93 & 99.99 & 76.89 \\
\hline
\end{tabular}

Table 11 Production data of ST09 before the improvement

\begin{tabular}{|c|c|c|c|c|c|}
\hline \multirow[b]{2}{*}{ Month (2014) } & \multirow{2}{*}{$\begin{array}{c}\text { Production } \\
\text { Plans } \\
\text { (Tons) }\end{array}$} & \multirow{2}{*}{$\begin{array}{c}\text { Good } \\
\text { Products } \\
\text { (Tons) }\end{array}$} & \multicolumn{3}{|c|}{ Loading } \\
\hline & & & $\begin{array}{l}\text { Wastes } \\
\text { (Tons) }\end{array}$ & $\begin{array}{l}\text { Time } \\
\text { (Hours) }\end{array}$ & $\begin{array}{l}\text { Downtime } \\
\text { (Hours) }\end{array}$ \\
\hline October & 102.65 & 97.78 & 4.88 & 601.92 & 92.16 \\
\hline November & 104.61 & 100.16 & 4.45 & 603.26 & 79.41 \\
\hline December & 58.23 & 55.08 & 3.15 & 328.92 & 40.19 \\
\hline Total & 265.49 & 253.01 & 12.47 & $1,534.10$ & 211.76 \\
\hline Average/Month & 88.50 & 84.34 & 4.16 & 511.37 & 70.59 \\
\hline
\end{tabular}

OEE before and after the improvement of ST09 are respectively calculated in Tables 13 and 14.

From Tables 13 and 14, it can be seen that the average per month of the equipment availability (A) is increased from 86.20 percent to 84.85 percent. The average per month of the performance efficiency is increased from 77.22 percent to 80.10 percent. The average per month of the quality rate 
Table 12 Production data of ST09 after the improvement

\begin{tabular}{|c|c|c|c|c|c|}
\hline \multirow[b]{2}{*}{ Month (2015) } & \multirow{2}{*}{$\begin{array}{c}\text { Production } \\
\text { Plans } \\
\text { (Tons) }\end{array}$} & \multirow{2}{*}{$\begin{array}{c}\text { Good } \\
\text { Products } \\
\text { (Tons) }\end{array}$} & \multicolumn{3}{|c|}{ Loading } \\
\hline & & & $\begin{array}{l}\text { Wastes } \\
\text { (Tons) }\end{array}$ & $\begin{array}{l}\text { Time } \\
\text { (Hours) }\end{array}$ & $\begin{array}{c}\text { Downtime } \\
\text { (Hours) }\end{array}$ \\
\hline January & 26.67 & 26.45 & 0.22 & 208.50 & 28.25 \\
\hline February & 260.29 & 258.12 & 2.18 & 544.75 & 85.50 \\
\hline March & 213.54 & 209.29 & 4.26 & 327.50 & 50.00 \\
\hline Total & 500.50 & 493.85 & 6.65 & $1,080.75$ & 163.75 \\
\hline Average/Month & 166.83 & 164.62 & 2.22 & 360.25 & 54.58 \\
\hline
\end{tabular}

Table 13 OEE of ST09 before the improvement

\begin{tabular}{lcccc}
\hline Month (2014) & $\mathrm{A}(\%)$ & $\mathrm{P}(\%)$ & $\mathrm{Q}(\%)$ & OEE (\%) \\
\hline October & 84.69 & 76.60 & 95.25 & 61.79 \\
November & 86.84 & 75.32 & 95.75 & 62.63 \\
December & 87.78 & 79.75 & 94.59 & 66.22 \\
Average/Month & 86.20 & 77.22 & 95.30 & 63.44 \\
\hline
\end{tabular}

Table 14 OEE of ST09 after the improvement

\begin{tabular}{lcccc}
\hline Month (2015) & $\mathrm{A}(\%)$ & $\mathrm{P}(\%)$ & $\mathrm{Q}(\%)$ & OEE (\%) \\
\hline January & 86.45 & 79.20 & 99.18 & 67.90 \\
February & 84.30 & 80.10 & 99.16 & 66.96 \\
March & 84.73 & 81.00 & 98.01 & 67.27 \\
Average/Month & 84.85 & 80.10 & 98.67 & 67.38 \\
\hline
\end{tabular}

is increased from 95.30 percent to 98.67 percent. As a result, the average per month of OEE is absolutely increased from 63.44 percent to 67.38 percent.

The production data of downtime and wastes of ST03 before the improvement during October to December 2015 and after the improvement from January to March 2015 are compared as the bar graphs in Figures 15 and 16.

It can be noticed from Figures 15 and 16 that the downtime is reduced from 174.78 hours to 83.36 hours after the improvement, while the wastes are decreased from 1,240 to 60 kilograms.

The comparison as the bar graphs of the production data of downtime and wastes of ST09 before the improvement during October to December 2015 and after the improvement from January to March 2015 are illustrated in Figures 17 and 18.

It can be seen from Figures 17 and 18 that the downtime is reduced from 211.76 hours to 163.75 hours after the improvement, while the wastes are decreased from 12,470 to 6,650 kilograms. 


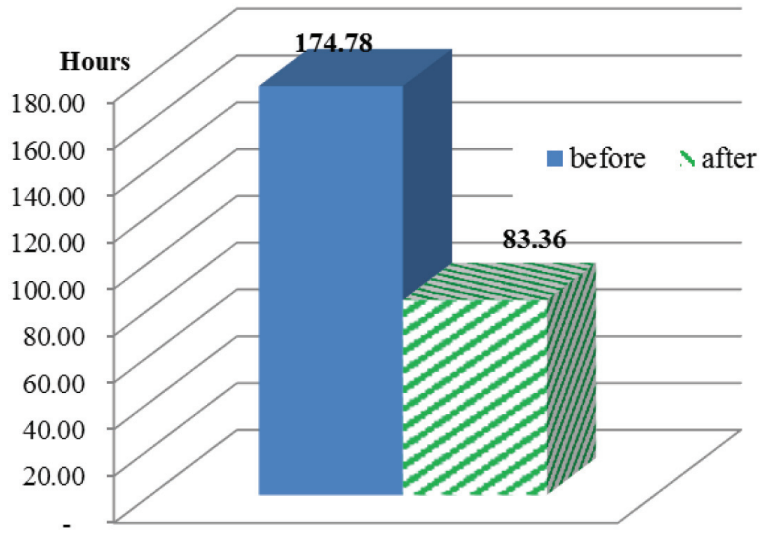

Figure 15 Downtime of ST03.

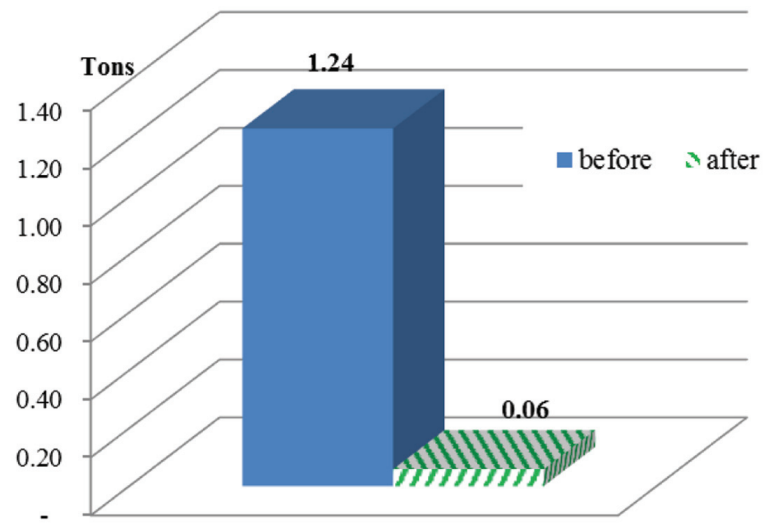

Figure 16 Wastes of ST03.

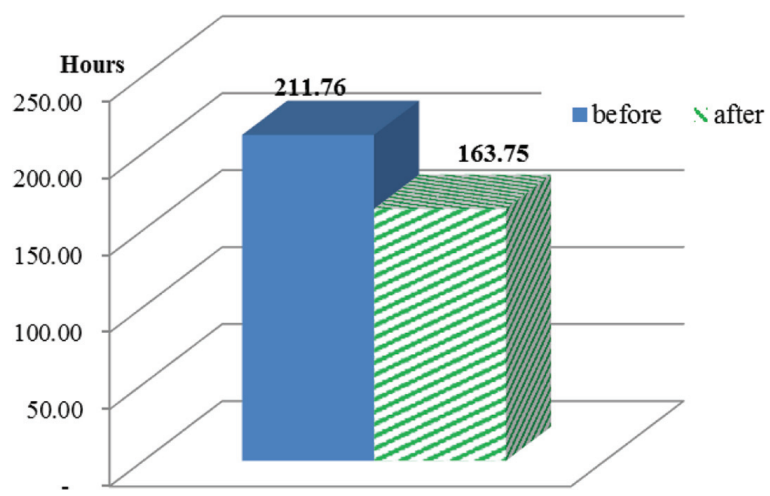

Figure 17 Downtime of ST09. 


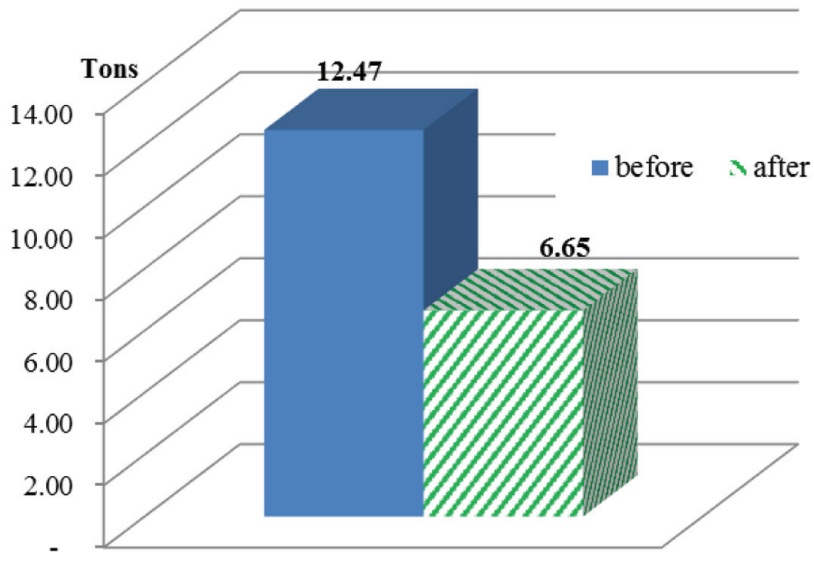

Figure 18 Wastes of ST09.

\section{Concusion}

The results from this paper show that TPM successfully gives the improvement. The wastes are decreased and the downtimes are also reduced. In addition, the aluminium stranded conductors have higher quality than before the improvement resulting in higher overall efficiency of the machines. These machines can be used to be the prototypes for operations of other machines of the company. Table 15 shows the comparison of OEE before and after the improvement. The results before and after the improvement can be summarized as below.

1) ST03 Prototype Machine: The downtime is reduced from $3,495.60$ minutes per month to 1667.20 minutes per month. The waste is decreased from 413.33 kilograms per month to 20 kilograms per month. Before the improvement, OEE is 70.97 percent. OEE after the improvement is 76.89 percent.

2) ST09 Prototype Machine: The downtime is reduced from $4,235.20$ minutes per month to $3,275.00$ minutes per month. The waste is decreased from 4,156.67 kilograms per month to 2,216.67 kilograms per month. Before the improvement, OEE is 63.44 percent. OEE after the improvement is 67.38 percent.

3) Total of ST03 and ST09 Prototype Machines: The downtime is reduced from $7,730,80$ minutes per month to $4,942.20$ minutes per month. 
The waste is decreased from 4,570.00 kilograms per month to 2,236.67 kilograms per month. Before the improvement, OEE is 67.21 percent. OEE after the improvement is 72.14 percent.

The following are suggestions for future research.

1) There are few operators for a big machine. Therefore, the extended period should be arranged for autonomous maintenance.

2) Other pillars of TPM should be activated.

3) Employment incentives should be offered to activate employees to work.

4) Due to slow collection of abnormality, the additional department should be offered for supporting the collection activities.

Table 15 Comparison of OEE before and after the improvement

\begin{tabular}{|c|c|c|c|c|c|c|}
\hline $\begin{array}{l}\text { Prototype } \\
\text { Machine }\end{array}$ & Indicator & Unit & Before & After & \multicolumn{2}{|c|}{ Difference } \\
\hline \multirow[t]{7}{*}{ ST03 } & Downtime & minute/month & $3,495.60$ & $1,667.20$ & decrease & $1,828.40$ \\
\hline & Wastes & $\mathrm{kg} / \mathrm{month}$ & 413.33 & 20.00 & decrease & 393.33 \\
\hline & Equipment & percent & 88.22 & 92.75 & increase & 4.53 \\
\hline & Availability (A) & & & & & \\
\hline & $\begin{array}{l}\text { Performance } \\
\text { Efficiency (P) }\end{array}$ & percent & 80.59 & 82.93 & increase & 2.34 \\
\hline & Quality Rate (Q) & percent & 99.82 & 99.99 & increase & 0.17 \\
\hline & $\begin{array}{l}\text { Overall Equipment } \\
\text { Efficiency (OEE) }\end{array}$ & percent & 70.97 & 76.89 & increase & 5.92 \\
\hline \multirow[t]{6}{*}{ ST09 } & Downtime & minute/month & $4,235.20$ & $3,275.00$ & decrease & 960.20 \\
\hline & Wastes & $\mathrm{kg} / \mathrm{month}$ & $4,156.67$ & $2,216.67$ & decrease & $1,940.00$ \\
\hline & $\begin{array}{l}\text { Equipment } \\
\text { Availability (A) }\end{array}$ & percent & 86.20 & 84.85 & decrease & 1.35 \\
\hline & $\begin{array}{l}\text { Performance } \\
\text { Efficiency (P) }\end{array}$ & percent & 77.22 & 80.10 & increase & 2.88 \\
\hline & Quality Rate (Q) & percent & 95.30 & 98.67 & increase & 3.37 \\
\hline & $\begin{array}{l}\text { Overall Equipment } \\
\text { Efficiency (OEE) }\end{array}$ & percent & 63.44 & 67.38 & increase & 3.94 \\
\hline \multirow[t]{6}{*}{ Total } & Downtime & minute/month & $7,730.80$ & $4,942.20$ & decrease & $2,788.60$ \\
\hline & Wastes & $\mathrm{kg} / \mathrm{month}$ & $4,570.00$ & $2,236.67$ & decrease & $2,333.33$ \\
\hline & $\begin{array}{l}\text { Equipment } \\
\text { Availability (A) }\end{array}$ & percent & 87.21 & 88.80 & increase & 1.59 \\
\hline & $\begin{array}{l}\text { Performance } \\
\text { Efficiency (P) }\end{array}$ & percent & 78.91 & 81.52 & increase & 2.61 \\
\hline & Quality Rate (Q) & percent & 97.56 & 99.33 & increase & 1.77 \\
\hline & $\begin{array}{l}\text { Overall Equipment } \\
\text { Efficiency (OEE) }\end{array}$ & percent & 67.21 & 72.14 & increase & 4.93 \\
\hline
\end{tabular}




\section{References}

[1] Joochim, O. and Meekaew, J. (2016). “Application of TPM in Production Process of Aluminium Stranded Conductors," in Proceedings of International Conference on Industrial Engineering, Management Science and Application, Jeju.

[2] Sethia, C. S., Shende, P. N., Dange, S. S. (2014). Total productive maintenance-a systematic review. Int. J. Sci. Res. Dev. 2, 124-127.

[3] Sütőová, A., Markulik, Š., Šolc, M. (2012). "Kobetsu Kaizen: its value and application," Proceedings of Electronics International Interdisciplinary Conference, 108-110.

[4] Gulati, R. (2013). Maintenance and Reliability Best Practice. 2nd edn. New York, NY: Industrial Press Inc.

[5] Sethia, C. S., Shende, P. N., and Dange, S. S. (2014). A case study on total productive maintenance in rolling mill. J. Emerg. Technol. Innov. Res. 1, 283-289.

[6] Hegde, H. G., Mahesh, N. S., and Doss, K. (2009). Overall Equipment Effectiveness Improvement by TPM and 5S Techniques in a CNC Machine Shop. SASTECH 8, 25-32.

[7] Paropate, R. V., and Sambh, R. U. (2013). The implementation and evaluation of total productive maintenance: a case study of midsized Indian enterprise. Int. J. Appl. Innovat. Eng. Manage. 2, 120-125.

[8] Siong, S. S., and Ahmed, S. (2007). "TPM Implementation Can Promote Development of TQM Culture: Experience from a Case Study in a Malaysian Manufacturing Plant," in Proceedings of International Conference on Mechanical Engineering, Dhaka, Bangladesh.

[9] Meekaew, J. (2015). Application of TPM for Productivity Improvement in Aluminium Conductor Stranding Production Process: A Case Study of Bangkok Cable Co., Ltd. Thonburi: King Mongkut's University of Technology.

[10] Nakajima, S. (1988). TPM Development Program. Cambridge: Productivity Press.

[11] Aumor, T. (2004). Total Preventive Maintenance, 2nd edn. Bangkok: Thailand Productivity Institute, 113-148. 


\section{Biographies}

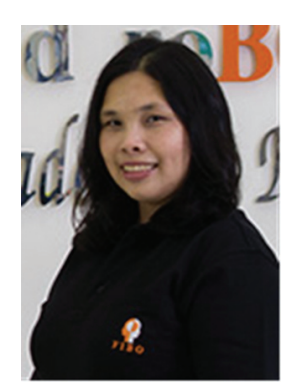

O. Joochim received her Bachelor and Master of Engineering in Electrical Engineering from Assumption University and King Mongkut's Institute of Technology Ladkrabang, Bangkok, Thailand, respectively. She received her Doctoral Degree in Economics and Management from Leibniz University Hannover, Germany. She is currently a lecturer at Institute of Field Robotics, King Mongkut's University of Technology Thonburi, Thailand. Before she has joined with Institute of Field Robotics, she was respectively with Partnership Management \& Project Follow-up and Vendor Performance Management Departments, Advanced Info Service PLC., Thailand.

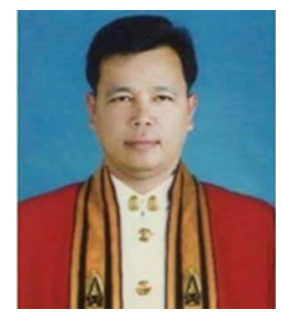

J. Meekaew received his Bachelor of Science in Technical Education (Electrical Power Engineering) from Rajamangala Institute of Technology Thewet, Bangkok, Thailand. He received his Master of Science in Technopreneurship from Institute of Field Robotics, King Mongkut's University of Technology Thonburi, Thailand. At present, he works with Bangkok Cable Co., Ltd. (Chachoengsao Factory), Thailand. 
